\title{
The Juridical Analysis on Effectiveness of Terrorism Prevention in the Digital Era
}

\author{
Azis Kurnia Afandi*) and Ira Alia Maerani**) \\ *) Grobogan Resort Police, E-mail: afand.wae.9@gmail.com \\ **) Faculty of Law Universitas Islam Sultan Agung
}

\begin{abstract}
This study aims to analyze juridically regarding the effectiveness of preventing acts of terrorism in the digital era. The method in this research is non-doctrinal. Based on the analysis conducted, it was found that currently, the implementation of digitalization-based terrorism prevention has not been able to materialize effectively, this is shown by the increasing recruitment of members of terrorism, financing of terrorism, and the spread of terror through digital media today. Act No. 5 of 2018 in its development has not regulated the implementation of a clear terrorism prevention and the position of the protection and recovery of victims of terrorism is not yet clear and regarding the progress of information and communication technology as a means of terrorism has not been clearly regulated. In addition, it has not yet been regulated related to efforts to prevent and deal with criminal acts of terrorism. So in other words, it can be said that the proliferation of advanced methods of terrorism has not been clearly regulated in the legal politics of handling terrorism.
\end{abstract}

Keywords: Digital Era; Effectiveness; Crime; Terrorism.

\section{Introduction}

Al-Qaeda views that the Internet is not only a method to reach media that is safer and faster, but also a turning point for the rise of effective communication strategies compared to traditional media. This is the first time that cyber-space has been able to allow direct communication between terrorists and their publics. The Internet not only fills the limitations of mass media, but the Internet also allows them to circumvent a number of moral rules contained in the mass media and limit their actions, and this is beneficial for their terrorism strategy. As jihadist groups did following the 2003 invasion of Iraq, the Internet not only allows them to avoid operational risks, but allows them to gain access by infiltrating traditional media systems such as Al-Jazeera. ${ }^{1}$ So it is clear that in dealing with terrorism, it is no longer possible to use traditional approaches. In its development, the approach to combating terrorism in Indonesia has undergone various changes.

The Reformation Era in Indonesia also affected law enforcement in terrorism cases. 11/PNPS/1963 was officially revoked through the enactment of Act No. 26 of 1999. While acts of terrorism such as bombings and suicide bombings continue to emerge, this time targeting houses of worship, crowd centers and embassies of friendly countries. The act of terrorism in Indonesia that attracted the most attention was the Bali Bombing 1 incident on October 12, 2002. The government responded quickly to this incident. After several years of countermeasures against

\footnotetext{
1Joseph E. Stiglitz and Linda J. Bilmes, The Three Trillion Dollar: The True Cost of the Iraq Conflict, WW Norton \& Company, Inc, New York, 2008, p. 23.
} 
acts of terrorism without a specific legal umbrella, this time the government issued Government Regulation in Lieu of Law (Perpu) number 1 of 2002. This regulation was later ratified into Act No. 15 of 2003, on the Eradication of Criminal Acts of Terrorism. This step was followed by Presidential Instruction Number 4 of 2002, which mandated the Coordinating Minister for Political and Security Affairs (Menkopolkam) to formulate national strategies and policies in dealing with terrorism. The Coordinating Minister for Politics and Security then issued a decree number 26/Menko/Polkam/11/2002, regarding the establishment of the Coordination Desk for Combating Terrorism (DKPT). ${ }^{2}$

After Perppu No. 1 of 2002 and Perppu No. 2 of 2002 was published, bomb terror attacks in Indonesia continue to occur. In fact, almost every year bomb terror attacks take place in remote parts of the archipelago. The terror attacks did not stop until Perppu No. 1 of 2002 was enacted as Act No. 15 of 2003 and Perppu No. 2 of 2002 was enacted as Act No. 16 of 2003 in early 2003. ${ }^{3}$ Then aAt the end of December 2002, for example, there was a bomb terror attack on a McDonald's restaurant in Makassar. In early 2003, there were bombs at the Jakarta Police Headquarters complex, Soekarno Hatta airport, bombs at the JW Marriot Hotel, bomb explosions at the Bukit Sampoddo Indah cafe, Luwu Regency, Palopo, bombs at the Australian Embassy in 2004, bombs in Pamulang, Tangerang, until Bali Bombing II in 2005. However, one of the defendants of the Bali bombing I at that time, Masykur Abdul Kadir then submitted a request for a judicial review of Act No. 16 of 2003 concerning the Implementation of Perppu No. 2 of 2002 concerning the Enforcement of Perppu No. 1 of 2002 to the Constitutional Court (MK). Finally, on July 23, 2004, the Constitutional Court annulled Act No. 16 of 2003. In their decision, the five panel of judges granted the request for a judicial review of Act No. 16 of 2003 because the enactment of the Law is contrary to the 1945 Constitution. This refers to Article 28I of the 1945 Constitution which states that the right not to be prosecuted on a retroactive basis is a human right that cannot be reduced under any circumstances. Meanwhile, four other panel of judges expressed a dissenting opinion.4Then in 2010, the National Counter-Terrorism Agency (BNPT) was officially formed based on Presidential Regulation no. 46 of $2010 .^{5}$

Then on January 14, 2016, there was an explosion and bomb attack on Jalan MH Thamrin, Sarinah building, Central Jakarta. The attack in the center of Jakarta shocked many parties. Coordinating Minister for Political, Legal and Security Affairs Luhut Binsar Panjaitan asked the DPR to revise Act No. 15 of 2003 concerning Eradication of Criminal Acts of Terrorism. The hope is that the new law can prevent terrorist acts in a preventive manner so that attacks do not occur. Furthermore, on February 11, 2016 the draft Anti-Terrorism Bill was submitted to the DPR. Then, the DPR formed a special committee to discuss the Anti-Terrorism Bill. This has clearly resulted in the legal politics of handling terrorism crimes not being able to realize the mandate of Pancasila and the 1945 Constitution of the

\footnotetext{
2Joseph E. Stiglitz and Linda J. Bilmes, Loc, cit. ${ }^{3}$ https://www.hukuonline.com/berita/baca/lt5b0531a3c651d/sekelumit-isah-perjalanan-uu-antiterrorism/ Retrieved 12 March 2020.

${ }^{4}$ Law online, Loc, cit.

5 Ibid
} 
Republic of Indonesia. This is clearly contrary to the hierarchical legislation in Indonesia which states that Pancasila is the legal basis in Indonesia. . Basically, legal politics in Indonesia must contain various values as reflected in the five precepts of Pancasila. Legal politics based on the value of God Almighty means that legal politics must be based on the moral value of God. Legal politics based on just and civilized human rights means that the existing legal politics must be able to guarantee respect and protection for human rights in a non-discriminatory manner. The problem of handling terrorism in Indonesia is caused by the political stagnation of the law of terrorism which is still a traditional law enforcement paradigm. In addition to the absence of a formulation related to prevention and mitigation in the existing terrorism law, the problem of poor coordination between related law enforcers is also a separate problem due to the lack of clear regulation of the task force coordination system that functions to eradicate terrorism. Sri Endah Wahyuningsih stated that there needs to be good coordination between existing law enforcement agencies regarding a problem of violating the law or existing crimes. ${ }^{6}$ In relation to coordination between these institutions, the existence of KKN problems in law enforcement also presents its own obstacles. Related to this Anis emphatically stated that: ${ }^{7}$ The destruction of the legal system is increasingly mushrooming with corruption, collusion, and nepotism intertwined with the temporary interests of law enforcement officers (even bureaucratic officials) at all levels of government.

The various issues above indicate that it is necessary to discuss further regarding the issue of the effectiveness of preventing criminal acts of terrorism at this time.

\section{Research Methods}

The type of legal research used is non-doctrinal. The approach in this paper is descriptive analytical. The method of data collection was carried out by field studies, literature studies, and document studies. The method of data analysis was qualitative.

\section{Results and Discussion}

\subsection{Prevention of Terrorism in the Digital Age in Indonesia}

David Held and Tony McGrew state that globalization is a process that manifests changes in the spatial organization of social relations and transactions. ${ }^{8}$ To explain this, Thomas Larrson argues that globalization is: ${ }^{9}$

\footnotetext{
${ }^{6}$ Sri Endah Wahyuningsih and Agus Sunaryo, THE ROLE OF PROSECUTOR OFFICE IN THE ERADICATION OF CORRUPTION CRIMINAL ACTS IN INDONESIA, Jurnal Pembaharuan Hukum Volume IV No. 2 May - August 2017, p. 248.

7 Anis Mashdurohatun and Bambang Tri Bawono, Penegakan Hukum Pidana Di Bidang Illegal Logging Bagi Kelestarian Lingkungan Hidup Dan Upaya Penanggulangannya, Jurnal Hukum Vol XXVI, No. 2, August 2011.

${ }^{8}$ Bagong Suyanto, Op. Cit.

${ }^{9}$ Thomas Larsson, 2001, The Race to The Top, The Real Story of Globalization, CATO Institute, Washington D. C., p. 9.
} 
...is the process of world shrinkage, of distances getting shorter, things moving closer. It pertains to the increasing ease with which somebody on one side of the world can interact, to mutual benefit, with somebody on the other side of the world. (the process of the world shrinking, distances getting shorter, things moving closer together. This refers to the increasing ease with which a person from one side of the world interacts with someone on the other side of the world mutually beneficially).

Basically, globalization has various positive and negative impacts. For example, with borderless conditions and ease of access as a result of globalization, of course the most visible impact is the easy access to all information from all corners of the world in the form of both positive and negative information. to the dynamics of the environment and understand the symptoms that are developing, but the negative side of the news also gives a heavy burden to the community, nowadays it is very easy for the community.

Advances in information and communication technology have then led to innovations for economic actors (consumers, job seekers, labor recruiters, and professionals), which make them a new tool in identifying and implementing economic and business opportunities. Not only has a good impact, other impacts arising from advances in information, communication and transportation technology which are increasingly shortening the distance between countries can lead to various national security problems, namely the problem of transnational crime, environmental damage, illegal immigrants, pirates, illegal fishing. illegal activities, terrorism, arms smuggling, trafficking in children and women, drugs. This situation is supported again by the advancement of information and communication technology which strengthens the borderless state crisis. ${ }^{10}$

This is because globalization is changing the way of life on a large scale by internationalizing western culture to all corners of the world. Therefore, the influence of globalization in everyday life is the same as the influence of globalization throughout the world. ${ }^{11}$ The existence of a negative side as a result of globalization is an unexpected result or consequence of modernization. Modernization as a result of globalization forms a uniformity of space and time for the international world through the establishment of connections between local authorities and global authorities.

For example, the terrorist group Al-Qaeda has used the Internet even before the events of September 11, 2001. The use of the Internet by Al-Qaeda is based on the reason that mass media such as television and magazines have recently threatened the security of their organizations and members. Television has limited time to broadcast long and dense news as the application of their ideology. In fact, mass media are considered unsafe by those who allow their messages to be picked up by interested parties and distort facts that influence public opinion on their

\footnotetext{
${ }^{10}$ Budi Winarno, 2014, Dinamika Isu-Isu Global Kontemporer,Jakarta, PT.Buku Seru, hlm. 168 dan 329, read Globalisasi Sebabkan Wabah Penyakit Sulit Terbendung accessed through https://tirto.id/globalisasi-karenakan-wabah-disease-dibendung-vXT, accessed February 11, 2021. ${ }^{11}$ Anthony Giddens, 2003, Runaway World Bagaimana Globalisasi Merombak Kehidupan Kita, PT. Gramedia Pustaka Utama, Jakarta, p. xvi.
} 
actions. $^{12}$ The Internet allows for rapid, low-risk, low-cost dissemination of information across a wide range of constituencies, from potential recruits to potential partners in terrorist organizations. ${ }^{13}$

The use of cyberspace also allows theorists to send out an attack that includes several successive attacks from just one place. Terrorists can carry out their actions from very far distances, even from different continents or countries with the Internet. Even if they use a computer close to their target area, terrorists do not need to be in the location so the use of cyberspace means that their actions do not have to sacrifice their members. ${ }^{14}$ For example, in the Middle East, the website of the Islamist militant group, Hezbollah, was created by Hamas supporters to announce their killing of a group of Jews. Cyber war occurred between Arabs and Jews. ${ }^{15}$ Not only as a medium for propaganda and cyber war, the internet is also used as a ground for terrorists to raise funds, coordinate attacks, and even conduct bomb-making training.

This further demonstrates the importance of continuing to reform the law, especially in the field of terrorism, so that the prevention and eradication of criminal acts of terrorism can run effectively. Currently, the policy of preventing criminal acts of terrorism digitally has not been able to be realized effectively. This problem can be seen in several cases at the EAST JAKARTA STATE COURT, which examines and hears criminal cases in the first instance using the Ordinary Examination Procedure and has rendered the following verdict in the case of the Defendant Bintang Juliardhi Als. Anggara Nusantara Als. Banu. The defendant was detained by Investigators at the National Police Headquarters from June 30, 2010 to October 28, 2010. During the investigation process at the police level, the examination of the accused is also carried out face-to-face between the investigator and the accused. the investigation process at the police level, has not used digital technology to facilitate case examination. In the verdict, the court stated that the Defendant Bintang Juliardhi Als. Anggara Nusantara Als. Banu. not proven guilty of committing a criminal act of terrorism as charged in the first and third indictments.

Based on the three cases above, it is clear that the terrorism cases carried out in the decade of 2011 to 2015 were mostly still using the vandalism method in the form of suicide bombings in places which are vital objects in people's lives. So that the digitalization method in preventing terrorism crimes was also not effective in that decade.

\subsection{Juridical Analysis of the Effectiveness of Preventing Terrorism in the Digital Age}

Act No. 5 of 2018 in its development has not regulated the implementation of a clear terrorism prevention and the position of the protection and recovery of

\footnotetext{
${ }^{12}$ Justin D. Banez, 2010, Thesis: The Internet and The Homegrown Jihadist Terrorism: Assessing U.S. Detection Techniques, Naval Postgraduate School, California, p. 16.

13P. Seib \& Janbek, D.M., 2011, Global Terrorism and New Media: The post-Al Qaeda generation, Routledge Taylor \& Francis Group, New York, p. 21.

${ }^{14}$ Eska, Op. Cit., p. 45.

${ }^{15}$ Eska, Loc, cit.
} 
victims of terrorism is not yet clear and regarding the progress of information and communication technology as a means of terrorism has not been clearly regulated. ${ }^{16}$ In addition, it has not yet been regulated related to efforts to prevent and deal with criminal acts of terrorism. So in other words, it can be said that the proliferation of advanced methods of terrorism has not been clearly regulated in the legal politics of handling terrorism. This fact resulted in terrorism growing and causing many victims.

This has clearly resulted in the legal politics of handling terrorism crimes not being able to realize the mandate of Pancasila and the 1945 Constitution of the Republic of Indonesia. This is clearly contrary to the hierarchical legislation in Indonesia which states that Pancasila is the legal basis in Indonesia. . Basically, legal politics in Indonesia must contain various values as reflected in the five precepts of Pancasila. Legal politics based on the value of God Almighty means that legal politics must be based on the moral value of God. Legal politics based on just and civilized human rights means that the existing legal politics must be able to guarantee respect and protection for human rights in a non-discriminatory manner.

\section{Closing}

Currently, the implementation of digitalization-based terrorism prevention has not been able to materialize effectively, this is shown by the increasing recruitment of members of terrorism, financing of terrorism, and the spread of terror through digital media at this time. There is a need for regulations related to surveillance, prevention, and eradication of terrorism through digital means and a system for implementing these regulations is needed that is supported by adequate facilities and infrastructure.

\section{References}

\section{Journal}

[1] Ahmad Zamzamy, Menyoal Radikalisme Di Media Digital, Jurnal Dakwah dan Komunikasi Islam, Volume 5, Nomor 1, February 2019

[2] Anis Mashdurohatun and Bambang Tri Bawono, Penegakan Hukum Pidana Di Bidang Illegal Logging Bagi Kelestarian Lingkungan Hidup Dan Upaya Penanggulangannya, Jurnal Hukum Vol XXVI, No. 2, August 2011

[3] Eska Nia Sarinastiti and Nabilla Kusuma Vardhani, Internet Dan Terorisme: Menguatnya Aksi Global Cyber-Terrorism Melalui New Media, Jurnal Gama Societa, Vol. 1 No. 1, January 2018

[4] Sri Endah Wahyuningsih and Agus Sunaryo, The Role Of Prosecutor Office In The Eradication of Corruption Criminal Acts In Indonesia, Jurnal Pembaharuan Hukum, Volume IV No. 2 May - August 2017

\section{Book}

16 P. Seib \& Janbek, DM, Op, cit. 
[1] Anthony Giddens, 2003, Runaway World Bagaimana Globalisasi Merombak Kehidupan Kita, PT. Gramedia Pustaka Utama, Jakarta

[2] Budi Winarno, 2014, Dinamika Isu-Isu Global Kontemporer, PT.Buku Seru, Jakarta

[3] Justin D. Banez, 2010, Thesis: The Internet and The Homegrown Jihadist Terrorism: Assessing U.S. Detection Techniques, Naval Postgraduate School, California

[4] Joseph E. Stiglitz and Linda J. Bilmes, 2008, The Three Trillion Dollar: The True Cost of the Iraq Conflict, WW Norton \& Company, Inc, New York

[5] P. Seib \& Janbek, D.M., 2011, Global Terrorism and New Media: The post-Al Qaeda generation, Routledge Taylor \& Francis Group, New York

[6] Soetandyo Wignjosoebroto, 2002, Hukum, Paradigma, Metode, dan Dinamika Masalahnya, HUMA,Jakarta

[7] Thomas Larsson, 2001, The Race to The Top, The Real Story of Globalization, CATO Institute, Washington D. C.

\section{Internet}

[1] Globalization Causes Disease Outbreaks to Be Unstoppable accessed via https://tirto.id/globalisasi-karenakan-wabah-disease-dibendung-vXT, accessed February 11, 2021.

[2] https://kabar24.bisnis.com/read/20191226/15/1184752/potret-terrorism2019-delapan-aksi-terorisme-275-pelaku-diciduk, Accessed April 12, 2020

[3] https://www.liputan6.com/news/read/3560945/kapolri-110-orangditangkap-terkait-teror-bom-surabaya, Accessed March 12, 2020

[4] https://peacelahindonesiaku.com/terrorism/sejarah-terrorism, Downloaded on March 12, 2020.

[5] https://www. Hukumonline.com/berita/baca/lt5b0531a3c651d/sekelumitisah-perjalanan-uu-anti-terrorism/ Accessed March 12, 2020

[6] https://udin3.mahkamahagung.go.id/, accessed on 12 May 2021

[7] https://www.government.nl/topics/counterterrorism-and-nationalsecurity/counterterrorism, Accessed May 12, 2021 